\title{
História oral e as artes: percursos, possibilidades e desafios
}

\author{
Ricardo Santhiago*
}

\section{Encontro epidérmico}

Este texto começa com uma conclusão: o mundo das artes não está entre os assuntos recorrentes da história oral feita no Brasil. Embora esse método (a entrevista) seja um recurso dos mais frequentes na abordagem das artes, seu campo é, como um todo, pouco atento ao assunto. A relação entre esses dois elementos na bibliografia erudita da incansavelmente expandida área de história oral, que desde os anos 1990 vem construindo a si própria como um espaço cada vez mais autônomo - em termos institucionais, ao menos -, é pouco significativa.

Trata-se de um diagnóstico algo inusitado, se levarmos em conta que se trata de um campo que tem como uma de suas figuras mais populares o estudioso italiano Alessandro Portelli, que se iniciou na prática da história oral porque começou a coletar canções populares ${ }^{1}$ e, ao fazer isso, percebeu que "algumas vezes as histórias que as acompanhavam eram mais interessantes e quase sempre mais imaginativas que as próprias canções" (Ciência do indivíduo, 1998). Ele mesmo sugere que a história oral seja, em si, considerada uma

* Mestre em História Social pela Faculdade de Filosofia, Letras e Ciências Humanas da Universidade de São Paulo (FFLCH/USP). Pesquisador do Grupo de Estudo e Pesquisa em História Oral e Memória da Escola de Artes, Ciências e Humanidades (GEPHOM/EACH/USP) e do Centro de Estudos em Música e Mídia (MusiMid). Estudante de doutorado do Programa de Pós-Graduação em História Social da Universidade de São Paulo, finaliza tese sobre a história oral no Brasil, com bolsa concedida pela FAPESP.

1 Conforme costumeiramente relatado em suas entrevistas; dentre elas, Rosati (2007). 
arte - estratégia que não apenas desvia dos debates estatutários quase sempre descolados da prática concreta de pesquisa, mas que também reconhece a história oral como uma "arte multivocal" (Portelli, 2010), uma "arte do diálogo" (Portelli, 1997), que combina os talentos da narração, da escuta, da troca, da atenção, da imaginação. "Eu penso que sejam obras de arte quase todos os contos que nós colhemos, são também obras de arte. Também, por isso, eu não gosto de falar de depoimentos, eu gosto de falar de estórias”, ele disse uma vez (Bessa et al., 2010, p. 40).

Ainda há mais: vários autores já discutiram as feições artísticas que um trabalho de história oral pode adquirir - no momento de tratamento textual, por exemplo. Inspirando-se na ideia pioneira de Dennis Tedlock (1975, 1983, 1990) em sua proposta de transcrição poética, Daphne Patai (1988) foi uma das pessoas que empreendeu essa discussão em seu livro com histórias orais de mulheres brasileiras, sendo, imitada por toda uma corrente de pesquisadores brasileiros que passou a utilizar a estratégia de literarização das entrevistas denominando-a de "transcriação", 2 termo tomado de empréstimo da teoria literária. ${ }^{3}$ A "literaricidade" da história oral tem levado até mesmo a exageros e simplificações a respeito do significado desse componente literário na narrativa pessoal e de sua transposição para a narrativa histórica. ${ }^{4}$

Outra conexão possível entre a história oral e o mundo das artes está na própria difusão de memórias recolhidas por meio de expressões artísticas. Elas têm sido a base dramatúrgica de espetáculos teatrais que no exterior formam uma tradição não apenas de prática, como também de reflexão. ${ }^{5}$ Mesmo a música popular tem visto trabalhos baseados em narrativas orais, como o CD Aparecida, de Iva Rothe (2010), criado a partir de uma série de entrevistas nas quais mulheres amazonenses responderam se "toda mulher é ou não é aparecida”, ou o CD Entrevista com Stela do Patrocinio (2007), de Lincoln Antonio e Georgette Fadel, inspirado nas falas de Stela

2 Sobre esse assunto, ver Santhiago (2011a).

3 Há um número grande de textos sobre transcriação em história oral, girando em torno dos mesmos argumentos. Um artigo representativo é o de Caldas (1999).

4 Uma das críticas a eles foi feita por Verena Alberti (2004), que argumenta que o reconhecimento do aspecto literário das narrativas de história oral não implica que tais narrativas não devam ser criticadas e analisadas de acordo com o instrumental erudito.

5 Ver, por exemplo: Schweitzer (2006); Pollock (2005); Friedman (2006). 
do Patrocínio, que anteriormente já haviam gerado um espetáculo músico-teatral de mesmo nome. ${ }^{6}$

Neste texto, meu propósito é verificar como a história oral tem se aproximado das artes enquanto assunto de pesquisa, focalizando os trabalhos que utilizam seu método para o estudo das artes: ${ }^{7}$ pintura, escultura, fotografia e outras artes visuais; design e criação digital; moda; arquitetura; poesia, literatura ficcional e não ficcional; música; teatro; dança; performance; cinema. A ênfase recai sobre o universo da cultura midiática; sobre o mundo das artes consagrado como um campo específico de produção cultural (Bourdieu, 2005), espaço relativamente autônomo no qual são produzidos e difundidos, intencionalmente, "artefatos com função estética" (Genette, 2001); sobre atividades criativas realizadas por indivíduos autointitulados (e externamente reconhecidos) como artistas, autores - inseridos em circuitos cuja função está na divulgação e na circulação das obras que eles criam. ${ }^{8}$ Sendo um balanço não exaustivo, o texto perde de vista filigranas e ocorrências isoladas, mas tem utilidade no apontamento de tendências e lacunas em relação ao assunto abordado.

\section{Em busca das artes}

Já se sabe que não há novidade alguma no uso de entrevistas por jornalistas, historiadores, sociólogos e outros profissionais dedicados à reconstrução de aspectos e períodos distintos da história das artes. São incontáveis os

6 Nesse caso, trata-se de um interessante circuito: as falas de Stela do Patrocínio foram gravadas em áudio por estagiárias da Colônia Juliano Moreira; foram transcritas, literarizadas e publicadas como poesia; e, depois, retornaram ao estado oral no $\mathrm{CD}$ e no espetáculo mencionados, bem como em vídeos e outros espetáculos teatrais. Esse circuito foi objeto de minha comunicação From mouth to page, from page to stage: oral history as art, apresentado na Southwest Oral History Association Conference, Visualizing oral history: final cuts, many uses, em abril de 2011. Ver também Patrocínio (2001).

7 Estou menos interessado, aqui, nos estudos que utilizam as artes como fontes - estudos que têm se multiplicado sob a vigência da história cultural.

8 Mantenho em fogo baixo a atenção a todas aquelas formas de expressão artística apartadas da cultura das mídias, geralmente descritas em termos como "culturas populares", "culturas tradicionais", "manifestaçôes tradicionais" etc., entre outras definiçôes sempre problemáticas e exaustivamente discutidas. Emprego a expressão "mundo das artes"; conquanto a ideia de "arte" e do que pode ser considerado um objeto artístico seja muito discutível, falar em "mundo das artes" permite reorientar o enfoque da discussão e tomar como objeto de análise, neste texto, os trabalhos sobre arte enquanto produtos culturais inseridos em circuitos de produção, difusão e circulação bem-estabelecidos. 
exemplos disso na constituição de biografias de personagens, de movimentos musicais, ou ainda de gerações - neles, as entrevistas são comumente utilizadas em seu nível informacional. O famoso biógrafo brasileiro Ruy Castro costuma dizer que dentro de suas investigações as entrevistas têm importância central: "Para cada biografia que faço [...] fiz uma média de 600 ou 700 entrevistas [...]. Uma média de até duzentos entrevistados por livro e nunca se fala uma vez só com a maioria dessas pessoas" (Castro, 2006, p. 182).

Em outros casos, o uso da entrevista na abordagem das artes toma a forma da autobiografia narrada, do relato autobiográfico em primeira pessoa, seja sob a forma da colaboração aberta (Lejeune, 2008) ou do ghostwriting. A entrevista editada pode assemelhar-se à biografia na busca por cronologia e linearidade (como ocorre na maior parte das centenas de livros da Coleção Aplauso, editada pela Imprensa Oficial $^{9}$ ); ao gênero memorialístico, quando organizada de acordo com outros recortes que não o temporal (como se vê nas memórias de Ronaldo Bôscoli, Eles e eu [Maciel; Chaves, 1993], ou de Roberto Menescal [Fonte, 2010]); ou combinar as duas estratégias (como fez Carla Mühlhaus [2003] com a história da figurinista Marilia Carneiro).

$\mathrm{O}$ volume, a variedade e o destaque desse tipo de trabalho são fenômenos de fácil explicação: sua origem reside no interesse público pelas vidas de artistas (como de outras celebridades), seja por mera curiosidade pessoal a respeito de histórias excepcionais, seja como auxílio em tentativas programadas de compreensão de suas obras. Para Leonor Arfuch (2010), numa análise de coletâneas de entrevistas com escritores, um diferencial dessas conversas é que o resultado delas

não se esgota na primeira publicação, mas antes se integra às palavras ditas no universo atribuível ao autor, com o mesmo status que suas cartas, diários íntimos, cadernos de notas, rascunhos, suscetível de ser citada como testemunho, de ser compilada em forma de livro, de se transformar em leitura teórica e, evidentemente, em material para uma biografia. (Arfuch, 2010, p. 214).

A autora sugere duas maneiras pelas quais as entrevistas podem se articular a outros materiais autobiográficos produzidos pelo artista: no caso de

9 Quase todos os livros da coleção, que atualmente está desativada, estão disponíveis em versão eletrônica no site: <http://aplauso.imprensaoficial.com.br/>. 
escritores que não escreveram autobiografias, as entrevistas poderiam atuar como uma espécie de "terreno iniciático" sobre o qual eles começariam a revisão de si; no caso daqueles que as escreveram, uma oportunidade de comentá-la, revê-la, acrescentar algo a ela.

São inumeráveis os exemplos de emprego de longas entrevistas na abordagem das artes. O valor delas nesse segmento está mais do que comprovado: enquanto instrumento para captação de informações, enquanto material editorial vendável, enquanto fonte acessória na interpretação de criações estéticas. Em 1978, o primeiro livro brasileiro sobre história oral, História oral: teoria e técnica, de Carlos Humberto Pederneiras Corrêa, já fazia uma apologia ao uso do método no estudo da arte brasileira, dentro de museus: "Quantos artistas tolhidos pela limitação natural da escrita falariam horas a fio de suas vidas, de seus trabalhos, desde a concepção até a conclusão final de suas obras, reconheceriam ou rejeitariam influências, contariam e desabafariam problemas", escreveu o autor (Pederneiras Corrêa, 1978, p. 85). Cabe perguntar, então, de maneira enfática: se o método da história oral parece tão conveniente ao estudo das artes, por que é que seu campo tem olhado de forma tão lateral para o assunto? É justo, antes de responder a essa indagação, examinar sua premissa - e um bom caminho seria apontado pelos espaços consagrados de difusão da história oral. ${ }^{10}$

As reuniões científicas estão entre eles. Se observamos seus números em perspectiva diacrônica, notamos que os prognósticos são positivos. O VI Encontro Nacional de História Oral, de 2002, computava apenas três trabalhos utilizando a história oral para o estudo do mundo das artes, ao passo que o XI Encontro Nacional de História Oral, dez anos depois, trazia mais de uma dezena de propostas com entrevistas com profissionais da dança, da poesia, do cinema, da fotografia, das artes plásticas, da música e do universo das escolas de samba. De forma geral, os eventos efetivamente têm tido cada vez mais atividades dedicadas às artes: o minicurso Teatro e história oral: a utilização da oralidade no processo criativo cênico e o GT Artes cênicas: dança, teatro, ópera, circo e performance, no VIII Encontro Regional Sudeste de História Oral (2009); o simpósio temático A oralidade e as artes cênicas no Brasil, no X Encontro Nacional de História Oral (2010); o simpósio temático

10 Um trabalho anterior já buscou fazer um mapeamento da utilização da história oral nas pesquisas em música, encontrando apenas três trabalhos e recomendando a aplicabilidade do método nessa área: Camacho (2008). 
História oral das artes, da cultura e da criatividade, no IX Encontro Regional Sudeste de História Oral (2011); o grupo de trabalho Arte, memória e oralidade, no VII Encontro da Região Norte de História Oral (2012); o simpósio temático Memória e cultura visual, no XI Encontro Nacional de História Oral (2012). No $17^{\circ}$ Encontro Internacional de História Oral, em 2012, foram inscritos mais de uma dezena de trabalhos de autores brasileiros sobre o mundo das artes.

As publicações, porém, oferecem um retrato menos promissor. Os 18 números da revista História Oral, principal periódico da área, publicados entre 1998 e 2011 são compostos por uma quantidade ínfima de artigos que tangenciam o mundo das artes: apenas cinco. ${ }^{11}$ Deles, três sugerem o uso das artes (música e literatura) enquanto fontes de pesquisa (Meihy, 2004, 2007; Passos, 2008); um não emprega história oral, mas cartas, entendendo-as como uma modalidade de "escrita de si" (Ionta, 2005); e o último trata da cultura popular (Guillen, 2006). Num segundo periódico, a revista Oralidades, a escassez é equivalente. Em seus dez números, publicados entre o primeiro semestre de 2007 e o segundo semestre de 2011, encontramos (além de trabalhos ligados a festas, tradições e culturas populares e de artigos que propõem a utilização da música como fonte para a história oral e para a história) apenas dois trabalhos sobre o mundo das artes; mais propriamente, duas entrevistas (Santhiago, 2007; Anjos; Lima; Almeida, 2008).

Uma parte expressiva da produção bibliográfica em história oral no Brasil está consubstanciada em obras multiautorais. ${ }^{12}$ Tomando por base seis coletâneas resultantes de encontros científicos promovidos pela Associação Brasileira de História Oral (Ferreira, 1994b; Meihy, 1996; Simson, 1997; Montenegro; Fernandes, 2001; Viscardi; Neves Delgado, 2006; Santhiago; Magalhães, 2013), chegamos a um universo de 116 artigos. Os temas mais numerosos são: questões teóricas e metodológicas (42 artigos), história da política (11 artigos), imigração (12 artigos) e história do trabalho ou de trabalhadores ( 9 artigos). Desse total de mais de uma centena de textos, apenas dois remetem ao mundo das artes (Duarte, 2001; Souza; Simson, 2006). Levando em conta outras 19 obras coletivas multitemáticas em torno dos eixos história oral, história e memória, ou estudos da oralidade (Ferreira,

11 Além deles, há um texto multimídia: Mauad (2010).

12 Algumas delas foram analisadas por Verena Alberti (1997). 
1994a; Gomes, 2000; Fenelon et al., 2004; Thiesen; Barros; Santana, 2005; Whitaker; Velôso, 2005; Worcman; Pereira, 2006; Fischman; Hartmann, 2007; Machado et al., 2008; Montenegro et al., 2008; Duarte; Frotscher; Laverdi, 2009; Jucá, 2009; Tettamanzy; Zalla; D’Ajello, 2010; Whitaker; Fiamengue; Velôso, 2010; Ewald et al., 2011; Duarte; Frotscher; Laverdi, 2011; Montenegro; Guimarães Neto; Acioli, 2011; Santhiago; Magalhães, 2011; VV. AA., 2011; Rollemberg, 2012), teremos um total de 241 artigos sobre os mais variados assuntos. Deles, apenas oito utilizam a história oral para o estudo das artes (Abrantes, 2005; Amorim, 2011; Camacho, 2008; Duarte, 2009; Duarte; González, 2011; Nascimento, 2009; Nogueira, 2000; Santhiago, 2011b).

Diante disso, alguém poderia argumentar que as artes ocupam as bordas ${ }^{13}$ não apenas da história oral, mas do campo historiográfico como um todo, ou mesmo das ciências humanas e sociais (à exceção das comunicações e artes) de maneira ampla. Não creio, porém, que essa seja uma boa réplica. Primeiramente porque, embora as artes possam de fato estar nas bordas do campo historiográfico, decerto sua distância em relação aos centros é de grau sensivelmente diferenciado. ${ }^{14} \mathrm{E}$, além do mais, porque, embora essa não seja uma questão apenas nossa, é nossa também.

\section{A exceção e a regra}

Não deixa de ser curioso que o mundo das artes ocupe as bordas do campo da história oral no Brasil - especialmente se considerarmos que uma de nossas matrizes é a experiência das unidades do Museu da Imagem e do

13 Remeto-me à semiótica da cultura e ao conceito de cultura das bordas, tal qual desenvolvido por Jerusa Pires Ferreira (2010). Já sinalizei uma aproximação ao conceito de bordas na minha interpretação da história oral no Brasil em Santhiago (2012b).

14 Seria bem-vindo um levantamento da produção sobre arte realizada em programas de pós-graduação em história ou difundida através de publicações e eventos da área; isso permitiria uma abordagem comparativa mais precisa. De qualquer maneira, um rápido sobrevoo por esse material sugere uma diferença de grau. As várias edições do Simpósio Nacional de História Cultural - que compreendem a "história cultural" não somente enquanto aproximação do tipo culturalista, mas também, em parte, como "história da cultura”, o demonstrariam. Um segundo exemplo: nas edições do Simpósio Nacional de História, já há simpósios temáticos decisivamente consagrados para a discussão das artes, como os de História \& música popular e o de História \& teatro. Para alguns textos de historiografia das artes, ver: Coli (2010), Lajolo (2010), Silva (2002). 
Som (MIS) pelo país. Especialmente os museus do Rio de Janeiro e de São Paulo criaram fabulosos acervos de histórias orais sobre as artes. $\mathrm{O}$ primeiro deles iniciou em 1966 o projeto Depoimentos para a posteridade, existente até hoje, que já em 1970 lançou o livro As vozes desassombradas do museu, com os depoimentos de Pixinguinha (gravados em outubro de 1966 e abril de 1968), João da Baiana (1966) e Donga (1969), coletados em sessões com múltiplos entrevistadores. O MIS paulista, por sua vez, já continha em sua carta de fundação, de 1970, a ideia de um programa de história oral, que teve vários desenhos e atingiu seu ápice enquanto projeto institucional com o trabalho de Sônia Maria de Freitas entre 1987 e 1992, quando ela implementou e coordenou o projeto Depoimentos em vídeo.

Além da experiência do MIS, existem outros trabalhos de história oral sobre o mundo das artes, marcados por solidez metodológica e vigor interpretativo, que têm tido repercussão expressiva. Embora quantitativamente escassos, eles têm sido levados a cabo por figuras e instituições de destaque no campo, como nos três casos a seguir.

Trabalho de referência é o de Olga Rodrigues de Moraes von Simson sobre o carnaval paulistano, defendido em 1989 e publicado quase duas décadas depois em uma edição que é, em si, artística. Inicialmente articulada a trabalhos canônicos de Maria Isaura Pereira de Queiroz (1992) sobre o carnaval, a pesquisa histórico-sociológica de Simson converteu-se em nova órbita. A ela vem se articulando uma série de trabalhos dela própria, de pesquisadores associados, como também de alunos, a respeito de temas correlatos, consolidando um conjunto muito expressivo de fontes e de reflexóes sobre a cultura paulista (Simson, 2011).

Assim como Simson, a pesquisadora Ana Maria Mauad tem se destacado nos estudos que relacionam história oral e cultura visual. Vários de seus escritos mais recentes (2008a, 2008b, 2009) têm como tema a trajetória de fotógrafos brasileiros, numa prática coletiva que tem entre seus resultados previstos um Dicionário histórico-biográfico da fotografia brasileira contemporânea. Mauad tem focado suas investigações no fotojornalismo - prática ora considerada arte, ora considerada comunicação, discussão que é retida nos próprios estudos: "Flávio Damm defende a idéia de que fotografia é uma arte, sim. Para ele, os grandes mestres da fotografia, como é o caso de Cartier-Bresson, legaram momentos de arte através da fotografia" (2005, p. 45), escreve a pesquisadora. 
Outro exemplo instigante é o oferecido por Karen Worcman, diretora do Museu da Pessoa, instituto que não raro tem artistas entre seus depoentes (Santos, 2008; Worcman; Santos, 2012). Quando conta a história de Dona Izabel Mendes, artesã do Vale do Jequitinhonha que cria bonecas em cerâmica, Worcman (2009) busca entender, a partir da narrativa da artista, sua disposição criativa, sua busca pela diferenciação, suas estratégias de negociação com o polo de consumo. A pesquisadora nota a necessidade de a artista colocar a si mesma como uma artesã especial, que não apenas fabrica objetos em argila com destreza, mas que agrega a esses objetos um "valor artístico maior"; "valor" simbolizado em sua avaliação monetária; "valor" irreprodutível, na medida em que "Izabel repete que não gosta de copiar modelos" (p. 103).

Mencionando uma experiência mais próxima ao meu próprio trabalho, aponto que pesquisadores do Centro de Estudos em Música e Mídia (MusiMid) têm tradicionalmente utilizado relatos orais no estudo da canção das mídias - entre os exemplos, vale mencionar a empreitada de Simone Luci Pereira $(2005,2007)$ estudando experiências de escuta de cançóes da bossa nova no Rio de Janeiro: ela analisa a relação entre produção e consumo, a atribuição de sentido às obras de arte por seus receptores, a consolidação da lembrança de escuta na memória pessoal. Sempre dentro da estratégia metodológica do centro de pesquisa, as entrevistas passaram a ser utilizadas em diálogo mais estrito com as perspectivas da história oral recentemente, o que resultou, por exemplo, em três pesquisas: a de Sonia Maria de Freitas (2012), que consiste em uma história oral de fadistas em São Paulo, sinalizando a existência de uma espécie de "resistência fadista" na cidade; a de Valéria Barbosa de Magalhães (2012), acerca da memória da música italiana a partir de entrevistas com mais de duas dezenas de imigrantes, na qual a autora notou que a canção napolitana padronizou a memória sobre a música,independente da geração ou da região de origem dos entrevistados; e a minha própria, sobre imigrantes argentinos e uruguaios que fazem tango na cidade de São Paulo, na qual tratei das representações do ofício musical como "trabalho" e como "utopia" em suas entrevistas (Santhiago, 2012a).

Além desses, seria possível encontrar um número significativo de trabalhos que empregam o método da história oral no estudo das artes se somássemos aquilo que circula dentro do campo com as obras que são produzidas e difundidas sem relação direta com ele. $\mathrm{O}$ conjunto a que cheguei evidentemente não é exaustivo; é impossível abranger tudo o que já foi feito, 
especialmente numa visada multidisciplinar. Essa é mais uma limitação dos balanços (ao lado da inexorabilidade de pasteurizar os trabalhos e descartar muitas de suas particularidades), mas em última instância indispensável para que eles se efetivem.

Os textos encontrados poderiam ser divididos conforme seis tipos de disposição central:

1 - Ênfase historiográfica - Trabalhos que enfocam a criação e a história de formações, gerações, grupos ou movimentos artísticos, como fizeram Flávio Teixeira (2007) estudando grupos teatrais no Recife, Izaías Almada (2004) estudando a história do Teatro de Arena, ou Alexandre Mate (2008) abordando a produção teatral paulistana na década de 1980, entre outros pesquisadores (Brandão, 2002; Almeida, 2007; Souza; Simson, 2007; Batista, 2010; Pederiva, 1998; Barbosa, 2011; Araújo, 2010; Vieira, 2009; Vargas; Perazzo, 2008; Ribeiro, 2010; Figueiredo, 2007; Lima, 2011).

2 - Ênfase biográfica - Trabalhos que buscam reconstituir a trajetória de vida de artistas, em narrações feitas por terceiros (Popolin, 2011; Meihy; Levine, 1994) ou por eles próprios; através da elaboração de textos analíticos (Velloso, 1997; Freire, 2005; Coli, 2012) ou da publicação de entrevistas, como fez Jerusa Pires Ferreira com o escritor Rubem Francisco Luchetti (2008) e com o músico Edvaldo Santana (2002). Podem-se acrescentar trabalhos realizados em mídias não escritas, como documentários, a exemplo daquele dirigido por Ana Carolina Maciel e Caco Souza sobre a atriz Eliane Lage (2007). Uma submodalidade dos trabalhos de cunho biográfico, com a operação de recortes, tem a forma do estudo de trajetória, enfocando aspectos determinados da formação e da vida profissional de artistas (Ribeiro, 2004; Duarte, 2001; Vilela, 2010; Silva, 1999; Drehmer, 1999; Rocha, 2008; Duarte, 2009). Também vale mencionar o trabalho que Geovanni Gomes Cabral vem desenvolvendo sobre o poeta José Costa Leite, estudando suas histórias orais e comparando-as com sua autobiografia.

3 - Enfase na identidade/subjetividade - Trabalhos que exploram artistas de trajetórias dessemelhantes, mas com marcadores identitários comuns. É o que fizeram Robson Xavier da Costa (2008) em seu estudo sobre artistas naif e Daisy Perelmutter tratando de artistas de origem judaica, entre outros pesquisadores (Duarte; González, 2011; Magalhães, 2002); 
4 - Ênfase sociológica - Estudos que se atêm menos às obras de arte e seus criadores do que às relações desses criadores com coletivos mais amplos: podem, para isso, relacionar a experiência artística ao conceito de sociabilidade, em circunstâncias de agrupamento social como a roda de samba (Giacomini, 2010), a participação em agremiações carnavalescas (Loner; Gill, 2009; Abrantes, 2005; Oliveira, 1989), ou o ensino de artes (Beaumont, 2003; Gonçalves, 2007); podem tratar de movimentos culturais coletivos e comunitários (Guarato, 2010; Nascimento, 2009), geralmente relacionando-os a circunscrições geográficas bem-delimitadas, ou ainda de grupos com origens comuns, como aqueles ligados a naturalidades, nacionalidades (Nogueira, 2000) ou a experiências de exclusão marcantes (Pena, 2007).

5 - Ênfase arquivística - A raiz desta vertente está nas experiências de depoimentos artísticos do MIS. A constituição de arquivos sobre as artes também encontra expressões, por exemplo, no Museu Clube da Esquina, ${ }^{15}$ criado pelo Museu da Pessoa, e no projeto História dos Artistas Mineiros (da fotografia e da dança) do Núcleo de História Oral da Universidade Federal de Minas Gerais. ${ }^{16}$ Existem também experiências mais localizadas como a do Centro de Documentação Musical da Universidade Federal de Pelotas (Cerqueira, 2008) e a de centros de memória ligados a instituições culturais, como o Centro de Documentação e Memória TUCA, do Teatro da Pontifícia Universidade Católica de São Paulo. ${ }^{17}$

6 - Ênfase na recepção - Estudos que enfocam os receptores de obras de arte. Entre outros pesquisadores (Junqueira, 2010; Gallo, 2003; Demarchi, 2008; Oliveira, 2011), Miriam Hermeto (2010) o fez, de maneira integrada à esfera da produção, em sua pesquisa sobre o espetáculo teatral Gota d'água. O território instigante da história oral com fãs, que extrapola a temática da experiência imediatamente estética ou da lembrança musical associada a eventos vividos, entraria nessa categoria, mas ainda é pouco explorado no Brasil. ${ }^{18}$

$15<$ http://www.museudapessoa.net/clube/>.

$16<$ <ttp://www.fafich.ufmg.br/his/historiaoral/index.php/por/Acervo-de-entrevistas $>$.

17 <http://www.teatrotuca.com.br/cdm/index.html>.

18 Fora do país, os estudos sobre fầs têm frequentemente recorrido a entrevistas. É o caso, por exemplo, de Berman (2008) e de Spataro (2010). 


\section{Os próximos passos}

Se não faltam profissionais que empregam o método da entrevista - e especialmente as entrevistas em profundidade - na abordagem das artes, poucos são os que engatam nesses estudos todo o lastro teórico e conceitual acumulado ao longo das últimas décadas na reflexão metodológica de nosso campo. Creio que a história oral poderia prestar mais atenção às artes porque está em condição de fazê-lo; pode oferecer contribuições em favor de um melhor aproveitamento das histórias narradas, por ser capaz de ir além de sua dimensão meramente informativa ou sua capacidade de reprodutibilidade autobiográfica.

O estudo das artes terá a ganhar se levarmos até ele as perspectivas da história oral a respeito da natureza e do funcionamento da memória, de seu caráter seletivo, de sua relação com o esquecimento; sua reflexão a respeito do caráter intersubjetivo e relacional, provisório e circunstancial, das entrevistas; sua consciência da distinção entre memória e história e da impossibilidade de estabelecimento completo da história passada; sua sensibilidade diante dos riscos da ilusão biográfica, do olhar retrospectivo, do olhar teleológico; sua possibilidade de aprofundamento, sua disponibilidade de tempo, sua escuta atenta. Ao mesmo tempo, o campo da história oral constituído como uma área específica teria a ganhar oferecendo espaço maior ao tema das artes. Embora o volume de trabalhos já apresentados seja considerável, sua representatividade no campo da história oral diminui conforme os filtros institucionais próprios ao campo.

As pesquisas já mencionadas sugerem alguns dos desenhos de pesquisa nos quais a história oral pode ser empregada no estudo das artes. Seria possível integrar a eles duas outras perspectivas: 1 ) a discussão de ideias sobre arte e de conceitos que informam o trabalho artístico; 2) o estudo dos processos de criação. Esses são caminhos que podem ser explorados tanto quando preparamos nossos projetos e conduzimos nossas entrevistas como quando reexaminamos entrevistas já realizadas, com esses fins.

Muitas entrevistas acabam discutindo, acidental ou propositalmente, as concepções de criadores sobre a arte, os conceitos subjacentes ao trabalho artístico, as ideias em jogo na produção ou na recepção de um objeto de arte, os propósitos do artista na criação. Essa aproximação não vem tendo destaque na história oral feita no Brasil, o que talvez se explique, ao menos 
em parte, pelo fato de esta ter sido especialmente marcada pela modalidade "história de vida", que direciona outro tipo de questionamento aos entrevistados. ${ }^{19}$ Livros com orientação jornalística, por outro lado, são mananciais para o estudo de ideias. Vozes do Brasil, de Patrícia Palumbo (2002; 2007), ou Estação Brasil, de Violeta Weinschelbaum (2006), são exemplos disso - bem como a excelente Coleção Encontros, da Azougue Editorial ${ }^{20}$ - mas poucas obras fazem frente ao majestoso A MPB em discussão (Naves; Coelho; Bacal, 2006), produzido por acadêmicos (mas não praticantes de história oral). ${ }^{21}$ Seja como for, o maior desafio não consiste na captação ou na edição e publicação de entrevistas; antes, reside em seu aproveitamento analítico. ${ }^{22}$

Um excelente modelo para tal aproveitamento está na obra de Richard Cándida Smith - da qual o livro Circuitos de subjetividade: história oral, o acervo e as artes (2012) é uma amostra -, historiador intelectual que tem abordado a história da cultura, especialmente das artes plásticas, nos Estados Unidos. Cándida Smith coloca que "narrativas de história oral podem [...] ser vistas como concretizações das teorias pessoais do criador e, como tal, elas têm muito em comum com a produção estética” (p. 93). O autor, obviamente, não considera que as entrevistas de história oral substituem as obras de arte, tampouco a interpretação que um analista tem condições de fazer a respeito delas - mas introduz os relatos orais em circuitos de leitura cuja potencialidade em muito supera a condição de fonte para uma história narrativa das artes.

Seja recorrendo exclusivamente a fontes orais ou lidando com uma variedade de fontes, Cándida Smith traz para o estudo da história da cultura a perspectiva do historiador intelectual. Sua obra descortina muitos caminhos para o emprego do método da história oral no estudo das artes. O ensaio $O$ valor dos objetos: a discussão de "qualidade" em entrevistas com

19 Dada a influência seminal da sociologia de Maria Isaura Pereira de Queiroz, da psicologia social de Ecléa Bosi, mas também da perspectiva que Aspásia Camargo injetou no projeto da Fundação Getúlio Vargas.

20 A coleção, nos casos de compilações de entrevistas com o mesmo artista, oferece a possibilidade de abordagem diacrônica dos relatos. Para os livros publicados, ver: <http://www.azougue.com.br >.

21 Seria possível mencionar, ainda, coletâneas de entrevistas com artistas plásticos, críticos, curadores, como as organizadas por Felipe Scovino (2009) e Glória Ferreira (2011), além de livros-depoimento de artistas publicados pela editora C/Arte, com artistas como Amilcar de Castro, Eymard Brandão e Solange Pessoa. Ver a coleção Circuito Atelier em: <http://www.comartevirtual.com.br >.

22 Aproveitamento que pesquisadores menos preocupados em coletar entrevistas do que em utilizá-las têm feito bem. Veja-se, por exemplo, Patriota (2010). 
historiadores da arte e curadores, integrante do livro Circuitos de subjetividade, por exemplo, é excepcionalmente instigante; ele discute o posicionamento colocado por historiadores e curadores, em suas entrevistas de história oral, a respeito do conceito de "qualidade" em arte. $\mathrm{O}$ autor aponta que, nesse caso, as fontes orais são instrumentos únicos na medida em que permitem um tipo acesso às ideias de curadores e historiadores que é diferenciado daquele comunicado na linguagem escrita, ou em exposições orais planejadas; com as entrevistas de história oral, seria possível alcançar os conceitos centrais para uma determinada prática profissional sob a forma da linguagem cotidiana, em um nível operacional. Nas palavras do autor, "entrevistas de história oral são uma janela para enxergar como os narradores individuais sintetizaram suas interpretações de discussões teóricas em um conjunto de valores práticos eficientes para se pensar sobre as tarefas do dia a dia” (p. 196).

As entrevistas, em casos como esses, não deveriam ser vistas como elementos que ajudam a "desvelar" a interpretação "correta" de um trabalho artístico, tampouco a verdadeira "intenção" de seu produtor, descartando assim a análise alijada do material de cunho biográfico - mas sim como traços narrativos atribuídos pelo entrevistado em uma circunstância determinada. Em comentários sobre obras autorais, por exemplo, as fontes orais funcionariam como elementos interpostos entre a ideia do autor e a leitura do intérprete, diminuindo o grau de abstração e descontinuidade entre as duas esferas e possibilitando uma terceira via interpretativa, que contemple os circuitos de recepção das obras de arte, que avalie o impacto da posicionalidade de um sujeito sobre as diferentes interpretações a respeito de uma obra artística.

Um segundo caminho passível de ser trilhado através da história oral seria a criatividade, ou, de modo menos abrangente, os processos de criação de artistas ou mesmo de outros criadores, como os intelectuais. Esse potencial não tem sido suficientemente explorado, ${ }^{23}$ seja na documentação do processo de criação artística, seja na produção de fontes narrativas sobre o processo. Ainda assim, existem indícios do interesse por essa abordagem. Livros que relatam as histórias de canções populares têm se tornado a cada ano mais comuns. ${ }^{24} \mathrm{~A}$ obra Entrevistas/Processos (VV. AA., 2003) - que reúne onze entrevistas de artistas originalmente produzidas para a Revista E, do SESC

23 Tenho conhecimento de um único artigo de história oral que tangencia essa abordagem, tratando de estilistas de moda: Godoi (2010).

24 Um exemplo destacado é o de Homem (2009). 
São Paulo - indica em sua orelha, assinada por Danilo Santos de Miranda, o "intuito [de] deixar grafado o processo de criação desses artistas nossos contemporâneos, como um legado às gerações futuras acerca das inquietações e dilemas dos tempos atuais", mesmo que a visada das entrevistas seja muito mais panorâmica do que localizada nesses processos. Um último exemplo, mais estimulante, é o livro 10/3=3/Cabral (Bagolin, 2012), reunião de conversas semanais gravadas entre os críticos de arte Luiz Armando Bagolin e Leon Kossovitch com o artista plástico Antonio Hélio Cabral, abordando o processo de criação deste último, especialmente das obras presentes no ateliê que lhes serviu de cenário - obras apresentadas ao leitor através das fotos de João Luiz Musa.

Estudos do processo de criação que se valham da história oral deverão ter um instrumental interdisciplinar claro, combinando um conhecimento vasto a respeito da história da arte estudada, de sua história política, de suas correntes estéticas, das redes artísticas etc. As entrevistas também mostrarão perspectivas múltiplas, que tocarão não apenas a dimensão psicológica das mesmas, mas também dimensões como a histórica - facultando interpretações a respeito da inserção histórica da criatividade artística - e a psicossocial - informando, por exemplo, sobre os ajustamentos de indivíduos excepcionalmente criativos, no ato de criação ou não, dentro de seus diferentes coletivos. Essa foi uma proposta esboçada por Paul Thompson (2008), que julgou valioso estudar o quanto certo grupo estimula, ou desestimula, a criatividade, acreditando ser importante saber "por que algumas comunidades estimulam a inovação ao passo que outras não [...]; que tipo de comunidade promove a criatividade” (p. 42). Esse seria um movimento possível para quem não entende a criatividade como "o ápice da realização individual", mas pressupõe que "os momentos de criação não são misteriosos produtos de um gênio, e sim de circunstâncias sociais complexas” (Schwartz, 1992, p. 18). Assim, a história oral ajudaria a desmitificar o processo criativo. Nas palavras, mais uma vez, de Cándida Smith:

A história oral tem se mostrado uma ferramenta especialmente poderosa para explorar esse tipo de questão. A narrativa de história oral, enquanto confluência de forças estéticas, psicológicas e sociais, pode revelar as interações entre subjetividade do entrevistado e as camadas da realidade que ele habita. Esta característica geral adquire significado e utilidade particulares nas entrevistas com artistas. 
Quando historiadores orais sentam-se diante de artistas e ligam os seus gravadores, passam a explorar o processo de autoquestionamento constante, dimensão central da atividade criativa. (Cándida Smith, 2012, p. 92).

Adotando essa linha, teríamos muito a aprender com a chamada "crítica genética”, cuja prática surgiu na década de 1960 com o intuito inicial de estudar manuscritos de escritores, operando assim uma reorientação no foco dos estudos literários, então calcados fundamentalmente no "texto". Passa-se para um enfoque distinto: "mais do que entender as estruturas de uma obra literária, o interesse agora se encontra em saber em que relações de poder essa estrutura surge, o que ela representa para o sujeito que a enuncia, como ela se projeta no leitor" (Pino, 2007, p. 24).

O movimento inicial da crítica genética pode ter lançado a oralidade para fora de seu domínio à medida que fez da fisicalidade seu sustentáculo primordial, circunscrevendo seus objetos a "documentos escritos, geralmente manuscritos, que, agrupados em conjuntos coerentes, formam a 'pré-história' de um texto e constituem o traço visível de um mecanismo criativo" (Gresillón, 2002, p. 155); vide a atenção que oferece aos aspectos materiais dos manuscritos: papéis, marcas d'água, caligrafia. Porém, a crítica genética transformou-se, de um campo de estudos de manuscritos, ao campo de estudos dos processos de criação. ${ }^{25}$ A palavra "manuscrito" já não compreende apenas materiais autógrafos, alargando-se para aquilo que Cecília Almeida Salles chama de "documentos de processo". Eles podem incluir a epistolografia, os arquivos digitais, a biblioteca do escritor, sua marginália, edições sucessivas da mesma obra, anotações, além de "depoimentos, entrevistas, diários, making off's" (Salles; Cardoso, 2007, p. 46), como fontes que auxiliam na interpretação dos dossiês de documentos de processo. Tampouco a crítica genética tem se restringido à obra literária. Nas palavras de Cecília Almeida Salles e Daniel Ribeiro Cardoso, "hoje, os estudos genéticos abarcam os processos comunicativos em sentido mais amplo, a saber, literatura, artes plásticas, dança, teatro, fotografia, música, arquitetura, jornalismo, publicidade etc." (p. 44).

A história oral (consubstanciada em entrevistas de qualquer tipo - história de vida, história temática, história de vida com orientação temática - que explorem a criação artística em suas potências cognitivas ou em suas

25 Sobre essa passagem, ver Willemart (2009). 
potências da vida prática ${ }^{26}$ ) poderia ser aplicada à crítica genética - hoje também chamada "crítica de processo" - de três maneiras:

1 - como um método que cria documentos de processo;

2 - como uma fonte que é documento de processo;

3 - como uma bússola para a crítica genética convencional.

No primeiro caso, a dimensão da história oral enquanto estudo do tempo presente, próximo ou imediato seria radicalizada. Tratar-se-ia de um trabalho colaborativo, próximo àquilo que Pierre-Marc de Biasi chama de estudo do processo em "statu nascendi": uma espécie de "novo tipo de solidariedade entre criação e pesquisa", na qual o pesquisador poderia se colocar "observando e apreendendo seu objeto em tempo real no seu próprio espaço de gênese", que possibilitaria um rico material ao investigador interessado no processo de criação. Ele acompanha o artista durante seu trabalho, de modo que às suas fontes

acrescentam-se a observação direta das condições de sua produção, a possibilidade de entrevistar seu autor, muitas vezes com a ocasião de localizar o efeito imediato de uma descoberta, de uma discussão, de um acontecimento fortuito que pode vir a ser determinante sem deixar nenhum traço escrito. (Biasi, 2002, p. 242).

Geram-se assim vestígios contemporâneos ao próprio objeto, mas criados por outros sujeitos. Nessa perspectiva colaborativa, trabalha-se tanto com a leitura de objetos estáticos quanto com um diálogo em processo, de modo que "a perspectiva processual, se levada às últimas consequências, não se limita, portanto, a documentos já produzidos, que, portanto, pertencem ao passado das obras" (Salles; Cardoso, 2007, p. 46). Ela permite de maneira exemplar a crítica do processo nas artes imateriais, que em princípio deixam poucos rastros não premeditados do caminho de criação. ${ }^{27}$

No segundo caso, mais fácil de ser executado, as fontes orais seriam produzidas a posteriori. Seriam documentos que não compartilham a mesma temporalidade da realização estética, e que são criados com uma distância temporal variável. Essa distância seria usualmente maior que a da carta, mas não impediria que esses dois recursos se acercassem naquilo que Marcos

26 Distinção feita por Benedetto Croce e discutida por Alfredo Bosi (2002).

27 Algo parecido foi feito, por exemplo, em Feinberg (2011). 
Antonio de Moraes (2007) colocou como a potencialidade das cartas no estudo genético: "revelar matrizes e circunstâncias da escritura, documentar lições elididas na versão de um texto publicado (e, eventualmente, conter a justificativa das escolhas realizadas)" (p. 73).

A história oral produziria, assim, documentos possuidores daquele "caráter retrospectivo que os coloca fora do momento da criação" (Salles, 1998) - não uma deficiência, mas uma característica. Mesmo quando o crítico genético trabalha com documentos coetâneos à criação, sua análise está colocada fora daquele momento. Além disso, os documentos de processo estão alienados do processo em si, de modo que mesmo o estudioso mais convencional lidará com um gap que é tanto temporal quanto espacial. Acreditar em qualquer tipo de acesso direto às circunstâncias criativas é um expediente ilusório, como os historiadores sabem bem. Esse não é um "risco" que apenas a história oral coloca.

Por outro lado, se ganha com a entrevista a memória da criação - ou então um elemento a mais para uma história da memória da criação. $\mathrm{O}$ praticante de história oral sabe fazer bom uso desse diferencial; tudo o que ele conhece sobre memória pode reinjetar o caráter propriamente processual da criação em seu caminho analítico. Historiadores, enquanto praticantes da ciência dos homens no tempo, ciosos das transformações em cronologias delimitadas, não teriam dificuldade para lidar com documentos de processo na reconstituição de um processo de criação.

Ao mesmo tempo - pelo menos desde que o texto A filosofia e os fatos, de Alessandro Portelli (1996), tornou-se campeão de citações -, sabemos bem que a ação de narrar está imbuída da ação de interpretar. Documentos de processo feitos a posteriori, independentemente de sua natureza oral ou escrita, devem ser entendidos como narrativas sobre as quais incidem a percepção do próprio artista acerca do seu processo de trabalho; acerca do resultado do trabalho, quando distanciado de quem o gerou; acerca da recepção do trabalho no intervalo de tempo entre sua produção e o instante de criação do registro de memória. O que o artista relata a respeito de seu processo criativo deve ser tomado como a representação que ele faz de uma parte de si mesmo. ${ }^{28}$

28 Essa foi uma das críticas mais recorrentes levantadas contra a história oral em seus diferentes estágios de consagração. Ela parece estar hoje superada dentro do campo, mas é frequentemente retomada por profissionais pouco familiarizados com sua literatura. No caso da crítica genética, há um caso instrutivo: Louis Hay, um dos fundadores desse campo de pesquisa, criador no Institut des Textes et 
Um estudo de processo de criação poderia articular as entrevistas, enquanto documentos de processo, a uma série de outras fontes: notas prévias, documentos contemporâneos ao processo (se existentes), diferentes versões da obra (gravações, manuscritos, rascunhos, conforme o caso), entrevistas oferecidas pelo artista à época da publicização do trabalho, resenhas etc. As histórias orais não cumpririam, assim, a mera função de preencher lacunas na ausência de outros documentos de processo - embora isso também seja viável, conforme Galciani Neves (2012, p. 548) comenta sobre seu trabalho sobre livros de artista:

O conteúdo das entrevistas foi transformado primeiramente em dossiês de criação, ou seja, em uma organização de informaçôes sobre obras, trajetória artística, entre outras questões, que se tornaram base para a elaboração de textos críticos com viés processual. Tais textos mesclam o percurso criativo do artista, a trama comunicacional, que conecta todas as suas obras, e as leituras de processo sobre a construção de livros de artista.

Histórias orais deveriam ser entendidas, dentro desse circuito, enquanto narração do projeto artístico e enquanto projeto artístico em si.

Por último, a história oral pode funcionar, dentro da crítica genética, como um registro capaz de fornecer pistas para a decifração, a organização, a datação dos documentos e, portanto, para a consolidação da proposta de um processo. Como uma bússola, ${ }^{29}$ as entrevistas podem oferecer mais inteligibilidade a todos os documentos quem instruem o estabelecimento de um processo criativo. Foi o que fizeram Anna Luiza Bauer e Maria Cecília César (1991) no estudo da criação poética de Beatriz Helena Ramos Amaral

Manuscrites Modernes abordou a validade dos testemunhos enquanto fontes para a crítica genética em um texto sobre a escritora e ensaísta alemã Christa Wolf, falecida em dezembro de 2011 - contemporânea, portanto, do pesquisador. É natural que ele, tão vinculado ao emprego dos manuscritos e à apreciação de sua fisicalidade, considere que o caminho aberto para o uso de outras fontes na pesquisa dos processos de criação seja uma avenida cheia de armadilhas. Para ele, o testemunho oral possui as falhas de ser "enganado pela memória" (Hay, 2007, p. 239) e de, eventualmente, impor ao pesquisador diretrizes (cronológicas, por exemplo) que não pertencem à pesquisa em si, mas à voz do autor da obra estudada. Ele critica o uso do testemunho oral como um recurso de autoridade passível de mau uso pelo pesquisador - como se este fosse considerá-lo a expressão verdadeira das intenções e dos procedimentos do autor.

29 Marieta de Moraes Ferreira (2002) é quem tem sugerido que a história oral é uma "bússola" para os desafios da história do tempo presente, exacerbando suas questôes. Inspiro-me no termo que ela cunhou, mesmo que o utilize em outro sentido. 
em Encadeamentos. Elas utilizaram diversos documentos de processo - rascunhos manuscritos e datilografados, mais o projeto do livro -, bem como depoimentos orais e escritos da autora. As entrevistas foram importantes para as pesquisadoras organizarem esse material, compreenderem a lógica de produção da escritora, entenderem os conceitos centrais que informam sua criação poética.

\section{Geleia geral}

Terá entendido mal quem enxergar este arrazoado de possibilidades como convite para o vernissage de lançamento de um novo campo acadêmico: uma "história oral das artes", ou uma "história intelectual-oral das ideias artísticas", ou uma "história oral do processo criativo". Quando escolhi para o subtítulo do livro Solistas dissonantes: história (oral) de cantoras negras (Santhiago, 2009) a expressão "história (oral)", eu quis sublinhar a viabilidade de uma rasura - sobre a palavra "oral" - e sugerir que tal rasura linguística só é possível dada a premência mesma dessa estratégia metodológica de constituição e utilização de fontes - as orais. Na orelha daquele livro, aliás, Jerusa Pires Ferreira perguntou: "E acaso há outro jeito de fazer história da música que não seja oral?”. Mesmo sabendo-a possível, Pires Ferreira não vê essa possibilidade como desejável. Igualmente, não há por que não reivindicarmos ao nosso campo, e ao tipo de pesquisa que empreendemos, um universo temático que tem se servido tanto das entrevistas e cuja exploração pode se beneficiar do corpo metodológico e teórico que acumulamos.

Igualmente, está por ser feita toda uma reflexão de teoria e método a respeito dos desafios específicos de se fazer história oral das artes. Pessoalmente, já fui estimulado a escrever sobre as particularidades de entrevistar artistas - de realizar gravações que possuem trechos mais assemelhados a "textos para recitação" do que a "recordações espontâneas", como ouvi David K. Dunaway dizer quando comentava o congelamento, a fixidez de histórias contadas por quem é entrevistado recorrentemente. ${ }^{30}$ Creio, contudo, que há

30 Isso ocorreu na sessão plenária The sound of music: musicians and oral history, durante a 46th Oral History Association Annual Meeting, em outubro de 2011, da qual também participaram Forrest Larson, Nick Merriwether, Lauren Onkey e Libby Van Cleve (moderadora). A principal discussão da mesa girou em torno da dificuldade de conseguir, nas entrevistas de história oral, ir além dos episódios e das 
muito a ser feito (e publicizado) em termos de trabalhos de campo antes que deles possamos despegar modelos, padrões, matrizes, menos informados por especulações abstratas e mais por experiências empíricas.

O chamamento à exploração da história oral do mundo das artes é animado por essa mesma perspectiva, menos retórica e mais pragmática, de integração: aquela que confia que a triagem e a combinação de visadas verticalizadas sobre os artistas, seus meios, objetos, tempos e cenários pode oferecer um conhecimento multifocal a respeito das artes e de suas múltiplas naturezas e conexões. Essa meta só será alcançada quando mais pesquisadores trouxerem, do mundo das artes, não a idolatria voltada a nomes canônicos, a tendências "de vanguarda" ou "do mercado", a nichos bem-estabelecidos e sedentos por commodities, a célebres inquestionáveis, a pontos finais e palavras acima de qualquer suspeita; mas antes os gestos de coragem e criatividade que levam adiante nossa (por que não, mesmo?) linha evolutiva. ${ }^{31}$

\section{Referências}

ABRANTES, V. L. C. Carnaval, blocos e escolas: o samba nos bairros portuários do Rio de Janeiro. In: THIESEN, I.; BARROS, L. O. C.; SANTANA, M. A. (Org.). Vozes do porto: memória e história oral. Rio de Janeiro: DP\&A Editora; UNIRIO, 2005. p. 111-121.

ALBERTI, V. Ensaio bibliográfico: obras coletivas de história oral. Tempo, v. 2, n. 3, p. 206 $219,1997$.

. História oral e literatura: questões de fronteira. In: Ouvir contar: textos em história oral. Rio de Janeiro: Editora FGV, 2004. p. 61-75.

ALMADA, I. Teatro de Arena. São Paulo: Boitempo, 2004.

ALMEIDA, P. C. Paisagens musicais da Zona Sul carioca: memórias e identidades da Bossa Nova. 123 p. Dissertação (Mestrado em Memória Social) - UNIRIO, Rio de Janeiro, RJ, 2007.

formas que os artistas repetem sistematicamente em entrevistas à imprensa. Embora eu não tenha deparado esse problema em minha própria experiência de pesquisa, sei que ele constitui um desafio comum em se tratando de história oral com pessoas públicas. Para mais informações sobre o trabalho de David K. Dunaway, ver, entre suas várias publicações, o excelente Singing out: an oral history of America's folk revivals (2010).

31 Em referência ao conceito célebre - e hoje controverso, mas inspirador - formulado por Caetano Veloso em sua famosa entrevista à Revista Civilização Brasileira, em 1966. Ver Campos (1968). 
AMORIM, M. A. B. V. Ser vedete no Brasil: uma vida em três tempos. In: VV. AA. Narrativas e experiências: histórias orais de mulheres brasileiras. 2. ed. São Paulo: Letra e Voz, 2011. p. 99-115.

ANJOS, C. V.; LIMA, J. D.; ALMEIDA, J. R. Um horizonte no lixo e nas letras: entrevista com Eliuza Mara de Carvalho. Oralidades: Revista de História Oral, São Paulo, v. 3, jan./ jun. 2008.

ARAÚJO, A. C. C. Sonhos em cena: histórias e memórias do Teatro Leopoldo Fróes. Revista ComUnigranrio, v. 2, n. 2, 2010.

ARENDT, H. A crise na cultura: Sua importância social e política. In: . Entre o passado e o futuro. São Paulo: Perspectiva, 1997.

ARFUCH, L. O espaço biográfico: dilemas da subjetividade contemporânea [2002]. Trad. P. Vidal. Rio de Janeiro: EdUERJ, 2010.

BAGOLIN, L. A. (Org.). 10/3=3/Cabral. São Paulo: Edusp, 2012.

BARBOSA, L. M. Sentimentos do blues fortalezense: compreensão da cena blues em Fortaleza 1988-1998. In: ENCONTRO INTERNACIONAL DE MÚSICA E MÍDIA, 7, 2011, São Paulo. Anais... São Paulo: MusiMid, 2011.

BATISTA, N. C. Descortinando o Grupo Galpão: a construção de uma ideologia a partir da história oral. In: ENCONTRO REGIONAL DA ANPUH-RIO, 14, 2010, Rio de Janeiro. Anais... 2010.

BAUER, A. L. C. C. A.; CÉSAR, M. C. S. F. Semiótica dos rascunhos - sintaxe das rasuras. Manuscrítica: Revista de Crítica Genética, São Paulo, n. 2, p. 65-75, 1991.

BAUMAN, Z. Comunidade: a busca por segurança no mundo atual [2001]. Trad. P. Dentzien. Rio de Janeiro: Zorge Zahar Ed., 2003.

BEAUMONT, M. T. Paisagens polifônicas da música na escola: saberes e práticas docentes. 148 p. Dissertação (Mestrado em Educação) - UFU, Uberlândia, MG, 2003.

BERMAN, G. "We're going to see the Beatles!": an oral history of beatlemania as told by the fans who where there. Santa Monica: Santa Monica Press, 2008.

BESSA, T. et. al. Entrevista com Alessandro Portelli. Projeto História, São Paulo, n. 41, p. 31-68, 2010.

BIASI, P. M. O horizonte genético. In: ZULAR, R. (Org.). Criação em processo: ensaios de crítica genética. São Paulo: Iluminuras, 2002. p. 219-244.

BOSI, A. Narrativa e resistência. In: . Literatura e resistência. São Paulo: Companhia das Letras, 2002. p. 118-135. 
BOURDIEU, P. As regras da arte: gênese e estrutura do campo literário. São Paulo: Companhia das Letras, 2005.

BRANDÃO, T. Ora, direis ouvir estrelas: historiografía e história do teatro brasileiro. Latin American Theatre Review, v. 36, n. 1, p. 67-91, 2002.

CALDAS, A. L. Transcriação em história oral. NEHO-História, n. 1, p. 71-79, 1999.

CAMACHO, V. C. Pesquisa em música: possibilidades do uso da história oral. In: MACHADO, C. J. S. et al. (Org.). Do silêncio à voz: pesquisas em história oral e memória. João Pessoa: Editora Universitária da UFPB, 2008. p. 167-180.

CAMPOS, A. Balanço da bossa: antologia crítica da moderna música popular brasileira. São Paulo: Perspectiva, 1968.

CÁNDIDA SMITH, R. Circuitos de subjetividade: história oral, o acervo e as artes. Trad. F. L. Cássio e R. Santhiago. São Paulo: Letra e Voz, 2012.

CASTRO, R. Vivos e mortos. In: WORCMAN, K.; PEREIRA, J. V. (Org.). História falada: memória, rede e mudança social. São Paulo: SESC SP; Museu da Pessoa; Imprensa Oficial, 2006. p. 180-188.

CERQUEIRA, F. V. et al. O Centro de Documentação Musical da UFPel no horizonte da multidisciplinaridade: articulações entre musicologia histórica, gestão patrimonial e memória institucional. História (São Paulo), Franca, v. 27, n. 2, p. 111-143, 2008.

CIÊNCIA do indivíduo. Entrevista concedida por Alessandro Portelli à Folha. Folha de $S$. Paulo, São Paulo, 7 jun. 1998.

COLI, J. A pintura e o olhar sobre si: Victor Meirelles e a invenção de uma história visual no século XIX brasileiro. In: FREITAS, M. C. (Org.). Historiografia brasileira em perspectiva. 6. ed. São Paulo: Contexto, 2010.

COLI, J. M. As vozes profissionais do cantor: a carreira de Niza de Castro Tank na Rádio Gazeta de São Paulo. In: COLI, J.; VALENTE, H. A. D. Entre gritos e sussurros: os sortilégios da voz cantada. São Paulo: Letra e Voz, 2012.

COSTA, R. X. Pintura naif: diálogos entre imagem e oralidade. Seculum: Revista de História, João Pessoa, n. 19, p. 103-25, jul./dez. 2008.

DEMARCHI, A. O poder das letras: Legião Urbana, juventude e experiência. In: GIUMBELLI, E.; DINIZ, J. C. V.; NAVES, S. C. (Org.). Leituras sobre música popular: reflexões sobre sonoridades e cultura. Rio de Janeiro: 7Letras, 2008. p. 193-209.

DREHMER, C. E. C. Violão, violonista e memória social nas décadas de 50 e 60 em Salvador. 205 p. Dissertação (Mestrado em História) - PUC-SP, São Paulo, SP, 1999. 
DUARTE, G. R. Entre modas, polcas e chamamés: música, identidade e transgressão na trajetória e na obra de Helena Meirelles. In: DUARTE, G. R.; FROTSCHER, M.; LAVERDI, R. (Org.). Práticas socioculturais como fazer histórico: abordagens e desafios teórico-metodológicos. Cascavel: Edunioeste, 2009. p. 183-207.

. Rádio e cultura popular: música caipira e música sertaneja. In: MONTENEGRO, A. T.; FERNANDES, T. M. (Org.). História oral: um espaço plural. Recife: Ed. Universitária UFPE, 2001.p. 321-330.

DUARTE, G. R.; FROTSCHER, M; LAVERDI, R. (Org.). Desplazamientos en Argentina y Brasil: aproximaciones en el presente desde la historia oral. Buenos Aires: Imago Mundi, 2011.

(Org.). Práticas socioculturais como fazer histórico: abordagens e desafios teóricometodológicos. Cascavel: Edunioeste, 2009.

DUARTE, G. R.; GONZÁLEZ, E. La construcción de si y del (en el) otro: desplazamientos de músicos en la Triple Frontera (Brasil/Argentina/Paraguay). In: DUARTE, G. R.; FROTSCHER, M.; LAVERDI, R. (Org.). Desplazamientos en Argentina y Brasil: aproximaciones en el presente desde la historia oral. Buenos Aires: Imago Mundi, 2011. p. $113-134$.

DUNAWAY, D. K.; BEER, M. Singing out: an oral history of America's folk revivals. New York; Oxford: Oxford, 2010.

EWALD, F. G. et al. (Org.). Cartografias da voz: poesia oral e sonora, tradição e vanguarda. São Paulo: Letra e Voz; Curitiba: Fundação Araucária, 2011.

FEINBERG, P. P. Making the invisible visible: documenting the creative process. 98 p. Tese (Mestrado em História da Arte) - Concordia University, Montreal, 2011. Disponível em: <http://spectrum.library.concordia.ca/7312/>. Acesso em: 24 jul. 2013.

FENELON, D. R. et. al. (Org.). Muitas memórias, outras histórias. São Paulo: Olho d'Água, 2004.

FERREIRA, G. Entrefalas. Porto Alegre: Editora Zouk, 2011.

FERREIRA, M. M. (Org.). Entre-vistas: abordagens e usos da história oral. Rio de Janeiro: Ed. FGV, 1994 .

$1994 b$.

(Org.). História oral e multidisciplinaridade. Rio de Janeiro: FINEP; Diadorim,

FERREIRA, M. M. História oral: una brujula para los desafios de la história. História, Antropologia e Fuentes Orales, n. 28, p. 141-152, 2002.

FIGUEIREDO, V. M. C. Gente em cena: fragmentos e memórias da dança em Goiás. 105 p. Tese (Doutorado em Educação) - UNICAMP, Campinas, SP, 2007. 
FISCHMAN, F.; HARTMANN, L. (Org.). Donos da palavra: autoria, performance e experiência em narrativas orais na América do Sul. Santa Maria: Editora UFSM, 2007.

FONTE, B. O barquinho vai...: Roberto Menescal e suas histórias. São Paulo: Irmãos Vitale, 2010.

FREIRE, A. V. Angel Vianna: uma biografia da dança contemporânea. Rio de Janeiro: Dublin, 2005.

FREITAS, S. M. Vozes do fado em São Paulo. In: ENCONTRO DE MÚSICA E MÍDIA, 8, 2012, São Paulo.

FRIEDMAN, J. Fractious action: oral history-based performance. In: CHARLTON, T. L.; MYERS, L. E.; SHARPLESS, R. (Org.). Handbook of oral history. Lanham; New York; Toronto; Oxford: Altamira Press, 2006.

GALLO, M. F. Memória da diversão: lembranças do circuito cinema-baile-teatro na cidade de Pindorama nas décadas de 1950 e 60. CONGRESSO INTERNO DE INICIAÇÃO CIENTÍFICA DA UNICAMP, 11, 2003, Campinas. Disponível em: <http://www.prp. unicamp.br/pibic/congressos/xicongresso/cdrom/pdfN/113.pdf>. Acesso em: 6 ago. 2013.

GENETTE, G. A obra de arte - volume 1: Imanência e transcendência. Trad. V. L. Siqueira. São Paulo: Littera Mundi, 2001.

GIACOMINI, S. M. "Samba é coisa nossa”: rodas de samba e sociabilidade na Renascença Clube, Rio de Janeiro. In: DÂNGELO, N. (Org.). História e cultura popular: saberes e linguagens. Uberlândia: EDUFU, 2010. p. 227-251.

GODOI, J.; GUIMARÃES, R. S. Do original à cópia: a voz dos estilistas sobre a criação da moda. Revista Emancipação, Ponta Grossa, v. 10, n. 1, p. 375-86, 2010.

GOMES, A. C. (Org.). Histórias de imigrantes e imigração no Rio de Janeiro. Rio de Janeiro: 7Letras, 2000.

GONÇALVES, L. N. Educação musical e sociabilidade: um estudo em espaços de ensinar/ aprender música em Uberlândia (Minas Gerais) nas décadas de 1940 a 1960. Em Pauta, Porto Alegre, v. 18, n. 31, 2007.

GRESILlÓN, A. “Devagar: obras”. In: ZULAR, R. (Org.). Criação em processo: ensaios de crítica genética. São Paulo: Iluminuras, 2002. p. 147-174.

GUARATO, R. O hip-hop como movimento cultural: as singularidades na cidade de Uberlândia/MG - 1970/2006. In: DÂNGELO, N. (Org.). História e cultura popular: saberes e linguagens. Uberlândia: EDUFU, 2010. p. 367-393.

GUILLEN, I. C. M. A formação de um mestre: saberes em circulação na cultura popular. História Oral, v. 9, n. 1, p. 107-123, 2006. 
HAY, L. Os trinta e três incipit de Christa Wolf. In: . A literatura dos escritores: questões de crítica genética. Trad. C. P. B. Mourão. Belo Horizonte: Editora UFMG, 2007.

HERMETO, M. "Olha a Gota que falta”: um evento no campo artístico-intelectual brasileiro (1975-1980). 439 p. Tese (Doutorado em História) - UFMG, Belo Horizonte, MG, 2010.

HOMEM, W. Histórias de canções: Chico Buarque. São Paulo: Leya, 2009.

IONTA, M. A escritura de si nas cartas de Anita Malfatti, Oneyda Alvarenga e Henriqueta Lisboa. História Oral, v. 8, n. 2, p. 145-168, 2005.

JUCÁ, G. N. M. (Org.). Memórias entrecruzadas: experiências de pesquisa. Fortaleza: EdUECE, 2009.

JUNQUEIRA, I. A. A. Tempo de lazer: cinema e cultura popular no cotidiano pratense na segunda metade do século XX. In: DÂNGELO, N. (Org.). História e cultura popular: saberes e linguagens. Uberlândia: EDUFU, 2010. p. 117-151.

LAJOLO, M. Regionalismo e história da literatura: quem é o vilão da história?. In: FREITAS, M. C. (Org.). Historiografia brasileira em perspectiva. 6. ed. São Paulo: Contexto, 2010 .

LEJEUNE, P. A autobiografia dos que não escrevem [1980]. In: __. O pacto autobiográfico: de Rousseau à internet. Belo Horizonte: Ed. UFMG, 2008. p. 113-191.

LIMA, S. R. Memórias que cantam e encantam: Coral Universitário da FAFI (2001-2011). União da Vitória: Coral Universitário da FAFI, 2011.

LONER, B. A.; GILL, L. A. Clubes carnavalescos negros na cidade de Pelotas. Estudos Ibero-Americanos, Porto Alegre, v. 35, n. 1, p. 145-162, jan./jun. 2009.

MACHADO, C. J. S. et al. (Org.). Do silêncio à voz: pesquisas em história oral e memória. João Pessoa: Editora Universitária da UFPB, 2008.

MACIEL, L. C.; CHAVES, A. Eles e eu: memórias de Ronaldo Bôscoli. Rio de Janeiro: Nova Fronteira, 1993.

MAGALHÃES, E. F. Rappers: artistas de um mundo que não existe - um estudo psicossocial de identidade a partir de depoimentos. 400 p. Dissertação (Mestrado em Psicologia) - USP, São Paulo, SP, 2002.

MAGALHĀES, V. B. Imigração e memória: a música italiana e os italianos em São Paulo. In: ENCONTRO DE MÚSICA E MÍDIA, 8, 2012, São Paulo.

MATE, A. L. A produção teatralpaulistana dos anos 1980 - R(ab)iscando com faca o chão da história: tempo de contar os (pré)juízos em percursos de andança. 340 p. Tese (Doutorado em História Social) - USP, São Paulo, SP, 2008. 
MAUAD, A. M. Flávio Damm, profissão fotógrafo de imprensa: o fotojornalismo e a escrita da história contemporânea. História (São Paulo), Franca, v. 24, n. 2, p. 41-78, 2005.

. Fontes de memória e o conceito de escrita videográfica: a propósito da fatura do texto videográfico Milton Guran em três tempos (LABHOI, 2010). História Oral, v. 14, n. 1, p. 141-151, 2010. v. 27, 2008a.

. Memórias do contemporâneo: a trajetória de Erno Schneider. Studium, Campinas, . Milton Guran, a fotografia em três tempos. Studium, Campinas, v. 28, 2009.

. O olhar engajado: fotografia contemporânea e as dimensões políticas da cultura visual. ArtCultura, Uberlândia, v. 10, p. 31-48, 2008 b.

MEIHY, J. C. S. B. Notas sobre a moderna 'tradição oral' na MPB: o fabulário árabe no imaginário brasileiro. História Oral, v. 10, n. 1, p. 113-130, 2007.

2004.

. O samba é Morena de Angola: oralidade e música. História Oral, v. 7, p. 121-143,

(Org.). (Re)introduzindo a história oral no Brasil. São Paulo: Xamã, 1996.

MEIHY, J. C. S. B.; LEVINE, R. M. Cinderela negra: a saga de Carolina Maria de Jesus. Rio de Janeiro: Editora UFRJ, 1994.

MONTENEGRO, A. T. et al. (Org.). História, cultura e sentimento: outras histórias do Brasil. Recife: Ed. Universitária UFPE; Cuiabá: Ed. da UFMT, 2008.

MONTENEGRO, A. T.; FERNANDES, T. M. (Org.). História oral: um espaço plural. Recife: Ed. Universitária UFPE, 2001.

MONTENEGRO, A. T.; GUIMARĀES NETO, R. B.; ACIOLI, V. L. C. (Org.). História, cultura, trabalho: questões da contemporaneidade. Recife: Ed. Universitária UFPE, 2011.

MORAES, M. A. Ligações perigosas. In: PINO, C. A. (Org.). Criação em debate. São Paulo: Humanitas, 2007. p. 65-76.

MÜHLHAUS, C. Marilia Carneiro no camarim das oito. Rio de Janeiro: Aeroplano; SENAC Rio, 2003.

NASCIMENTO, F. G. C. As veias culturais do manguebit. In: JUCÁ, G. N. M. (Org.). Memórias entrecruzadas: experiências de pesquisa. Fortaleza: EdUECE, 2009. p. 135-146.

NAVES, S. C.; COELHO, F. O.; BACAL, T. (Org.). A MPB em discussão: entrevistas. Belo Horizonte: Editora UFMG, 2006. 
NEVES, G. A entrevista como estratégia metodológica para a crítica de processo. In: CONGRESSO INTERNACIONAL DA ASSOCIAÇÃO DE PESQUISADORES EM CRÍTICA GENÉTICA, 10, 2012, Porto Alegre. Anais...Porto Alegre: EdiPUCRS, 2012. p. 544-552.

NOGUEIRA, A. M. M. No ritmo da banda: histórias da comunidade lusa da Ponta d'Areia. In: GOMES, A. C. (Org.). Histórias de imigrantes e imigração no Rio de Janeiro. Rio de Janeiro: 7Letras, 2000. p. 183-206.

OLIVEIRA, A. M. A Jovem Guarda e a indústria cultural: análise da relação entre o movimento Jovem Guarda, a indústria cultural e a recepção de seu público. 111 p. Dissertação (Mestrado em História) - UFF, Niterói, RJ, 2011.

OLIVEIRA, J. L. Uma estratégia de controle: a relação do poder do estado com as escolas de samba do Rio de Janeiro no período de 1930 a 1985. Dissertação (Mestrado em História) UFRJ, Rio de Janeiro, RJ, 1989.

PALUMBO, P. Vozes do Brasil. São Paulo: DBA, 2002. . Vozes do Brasil 2. São Paulo: DBA, 2007.

PASSOS, M. Nas fronteiras do bem e do mal: oralidade e narrativa em Guimarães Rosa. História Oral, v. 11, n. 1-2, p. 105-126, 2008.

PATAI, D. A face evanescente do humanismo. In: . História oral, feminismo e politica. Trad. F. L. Cássio e R. Santhiago. São Paulo: Letra e Voz, 2010. p. 143-156.

. Brazilian women speak: contemporary life stories. New Brunswick: Rutgers University Press, 1988.

PATRIOTA, R. Pela palavra e pela imagem: Camaradas [Strindberg] na cena brasileira contemporânea pela encenação do grupo Tapa. In: RAMOS, A. F.; CAPEL, H. S. F.; PATRIOTA, R. (Org.). Criações artísticas, representações da história. São Paulo: Hucitec; Goiânia: Editora PUC-GO, 2010. p. 132-155.

PATROCÍNIO, S. Reino dos bichos e dos animais é o meu nome. Org. e apr. Viviane Mosé. Rio de Janeiro: Azougue Editorial, 2001.

PEDERIVA, A. B. A. Jovens tardes de guitarras, sonhos e emoções: fragmentos do movimento musical Jovem Guarda. 281 p. Dissertação (Mestrado em História) - PUC-SP, São Paulo, SP, 1998.

PEDERNEIRAS CORRÊA, C. H. História oral: teoria e técnica. Florianópolis: UFSC, 1978.

PENA, P. C. A. A mão que segura o spray: a resistência, a identificação e a pedagogia dos grafiteiros de Salvador. 121 p. Dissertação (Mestrado em Educação e Contemporaneidade) - UNEB, Salvador, BA, 2007. 
PEREIRA, S. L. Escutando memórias: uma abordagem antropológica para o estudo da canção das mídias. In: VALENTE, H. A. D. (Org.). Música e mídia: novas abordagens sobre a canção. São Paulo: Via Lettera; FAPESP, 2007. p. 147-173.

O nome, o olhar e a escuta da cidade. In: ULHÔA, M.; OCHOA, A. M. (Org.). Música popular na América Latina: pontos de escuta. Porto Alegre: UFRGS, 2005.

PERELMUTTER, D. Intérpretes do desassossego: memórias e marcas sensíveis de artistas brasileiros de ascendência judaica. 200 p. Tese (Doutorado em História) - PUC-SP, São Paulo, SP, 2004.

PINO, C. A. Gênese da gênese. Ciência e Cultura, ano 59, n. 1, p. 24-27, jan./mar. 2007.

PIRES FERREIRA, J. Cultura das bordas: comunicação, edição, leitura. Cotia: Ateliê, 2010. . Entrevista com Edvaldo Santana. Projeto História, São Paulo, v. 24, p. 381-413, 2002. 2008.

POLLOCK, D. (Org.). Remembering: oral history performance. New York; Basingstoke: Palgrave Macmillan, 2005.

POPOLIN, C. M. Da Áustria ao Paraná: a trajetória imagética de Hans Kopp, primeiro fotógrafo de Rolândia (PR). Discursos Fotográficos, Londrina, v. 7, n. 10, p. 273-274, 2011.

PORTELLI, A. A filosofia e os fatos: narração, interpretação e significado nas memórias e nas fontes orais. Revista Tempo, v. 1, n. 2, p. 59-72, 1996.

. Sempre existe uma barreira: a arte multivocal da história oral. In: .Ensaios de história oral. Trad. F. L. Cássio e R. Santhiago. São Paulo: Letra e Voz, 2010. p. 19-35. . The battle of Valle Giulia: oral history and the art of dialogue. Madison; London: The University of Wisconsin Press, 1997.

QUEIROZ, M. I. P. Carnaval brasileiro: o vivido e o mito. São Paulo: Brasiliense, 1992.

RIBEIRO, M. A. História da arte e história oral na leitura da obra de Iole de Freitas. In: COLÓQUIO DO COMITÊ BRASILEIRO DE HISTÓRIA DA ARTE, 24, 2004, Belo Horizonte. Anais... Belo Horizonte: Comitê Brasileiro de História da Arte, 2004. p. 371 379 .

RIBEIRO, R. A. C. Errância e exílio na soul music: do movimento Black-Rio nos anos 70 ao Quarteirão do Soul em Belo Horizonte, 2010. Tempo e Argumento, Florianópolis, v. 2, n. 2, p. 154-180, jul./dez. 2010. 
ROCHA, R. M. A trajetória de Gianni Ratto na indumentária. 228 p. Dissertação (Mestrado em Teoria e Prática de Teatro) - USP, São Paulo, SP, 2008.

ROLLEMBERG, D. (Org.). Histórias de vida: experiências com história oral. Niterói: Editora da UFF, 2012.

ROSATI, I. Alessandro Portelli: "Ho imparato come gli artigiani, rubando com gli occhi". In: CASELLATO, A. (Org.). Il microfono rovesciato: 10 variazioni sulla storia orale. Treviso: Istresco, 2007. p. 55-68.

SALLES, C. A. Poder de descoberta. Manuscritica, São Paulo, n. 7, p. 83-90, 1998.

SAlleS, C. A.; CARDOSO, D. R. Critica genética em expansão. Ciência e Cultura, Campinas, ano 59, n 1, p. 44-47, jan./mar. 2007.

SANTHIAGO, R. A discreta essencialidade de Tata Fernandes. In: VV. AA. Narrativas e experiências: histórias orais de mulheres brasileiras. 2. ed. São Paulo: Letra e Voz, 2011b. p. 71-98.

. Al tango lo canto así: música, trabalho e utopia. In: VALENTE, H. A. D. Dónde estás corazón? O tango no Brasil, o tango do Brasil. São Paulo: Via Lettera, 2012a. p. 173189.

. "Eu sonhava e via tudo": entrevista com Tetê Espíndola. Oralidades, São Paulo, n. 1, p. 151-161, jan./jun. 2007.

. "If you know Portuguese you know what this is": o papel da tradução na história oral do Brasil. In: SANTHIAGO, R.; MAGALHÃES, V. B. (Org.). Memória e diálogo: escutas da Zona Leste, visões sobre a história oral. São Paulo: Letra e Voz; FAPESP, 2011 a. p. $137-152$.

. Museu de grandes novidades: história oral como história pública. In: ENCONTRO DE ESTUDOS RURAIS E URBANOS, 39, 2012b.

. Solistas dissonantes: história (oral) de cantoras negras. São Paulo: Letra e Voz, 2009.

SANTHIAGO, R.; MAGALHĀES, V. B. (Org.). Depois da utopia: a história oral em seu tempo. São Paulo: Letra e Voz, 2013.

- (Org.). Memória e diálogo: escutas da Zona Leste, visões sobre a história oral. São Paulo: Letra e Voz; FAPESP, 2011.

SANTOS, J. (Org.). Memórias de brasileiros: uma história em todo canto. São Paulo: Peirópolis; Museu da Pessoa, 2008.

SCHWARTZ, J. O momento criativo. São Paulo: Editora Best-Seller, 1992. 
SCHWEITZER, P. Reminiscence Theatre: making theatre from memories. London; Philadelphia: Jessica Kingsley Publications, 2006.

SCOVINO, F. Arquivo contemporâneo. Rio de Janeiro: 7Letras, 2009.

SILVA, R. D. C. Cotidiano, memória e tensões: a trajetória artística das cantoras do rádio de Salvador de 1950 a 1964. Dissertação (Mestrado em História) - PUC-SP, 1999.

SILVA, T. B. Ora, direis ouvir estrelas: historiografia e história do teatro brasileiro. Latin American Theatre Review, v. 36, n. 1, p. 67-91, 2002.

SIMSON, O. R. M. Brancos e negros no carnaval popular paulistano (1914-1989). 340 p. Tese (Doutorado em Sociologia) - USP, São Paulo, SP, 1989.

. Carnaval em branco e negro: carnaval popular paulistano (1914-1988). São Paulo: Edusp; Imprensa Oficial; Campinas: Editora da Unicamp, 2007.

. O samba paulista e suas histórias: textos, depoimentos orais, músicas e imagens na reconstrução da trajetória de uma manifestação da cultura popular paulista. In: ENCONTRO INTERNACIONAL DE MÚSICA E MÍDIA, 7, 2011, São Paulo: MusiMid, 2011.

1997.

. (Org.). Os desafios contemporâneos da história oral. Campinas: CMU-Unicamp,

SOUZA, E. C.; SIMSON, O. R. M. Roda de samba: espaço da memória, educação e sociabilidade. In: VISCARDI, C. M. R.; NEVES DELGADO, L. A. (Org.). História oral: teoria, educação e sociedade. Juiz de Fora: Ed. UFJF, 2006. p. 137-146.

SPATARO, C. Sexualidades, cuerpos e historias de amor en la música romántica: configuración de identidades de género en un club de fans de Ricardo Arjona. Cadernos do Tempo Presente, n. 1, out. 2010.

TEDLOCK, D. From voice and ear to hand and eye. The Journal of American Folklore, v. 103, n. 408, p. 133-156, 1990. 1975.

. Learning to listen: oral history as poetry. Boundary 2, v. 3, n. 3, p. 707-728, spring

. The spoken word and the work of interpretation. Philadelphia: University of Pennsylvania Press, 1983.

TEIXEIRA, F. W. O movimento e a linha: presença do Teatro de Estudante e d'O Gráfico Amador no Recife (1946-1964). Recife: Ed. Universitária UFPE, 2007.

TETTAMANZY, A. L. L.; ZALLA, J.; D’AJELLO, L. F. T. (Org.). Sobre as poéticas do dizer: pesquisas e reflexões em oralidade. São Paulo: Letra e Voz, 2010. 
THIESEN, I.; BARROS, L. O. C.; SANTANA, M. A. (Org.). Vozes do porto: memória e história oral. Rio de Janeiro: DP\&A Editora; UNIRIO, 2005.

THOMPSON, P. Community and creativity: a life stories perspective. Oral History Journal, v. 37, n. 2, p. 34-44, 2008.

VARGAS, H.; PERAZZO, P. F. A jovem guarda no ABC Paulista: música popular, mídia e memória. Sociedade e Cultura, v. 11, n. 2, p. 225-232, jul./dez. 2008.

VELLOSO, M. P. Mário Lago: boemia e política. Rio de Janeiro: Ed. FGV, 1997.

VIEIRA, A. P. Dançando nos espaços das rupturas: olhares sobre influências das danças moderna e expressionista no Brasil. Fênix: Revista de História e Estudos Culturais, v. 6, n. 3, 2009 .

VILELA, Lilian Freitas. Uma vida em dança: movimentos e percursos de Denise Stutz. 150 p. Tese (Doutorado em Educação) - UNICAMP, Campinas, SP, 2010.

VISCARDI, C. M. R.; NEVES DELGADO, L. A. (Org.). História oral: teoria, educação e sociedade. Juiz de Fora: Ed. UFJF, 2006.

VV. AA. Entrevistas/Processos. São Paulo: SESC São Paulo; Lazuli Editora, 2003.

VV. AA. Narrativas e experiências: histórias orais de mulheres brasileiras. 2. ed. São Paulo: Letra e Voz, 2011.

WEINSCHELBAUM, V. Estação Brasil: conversas com músicos brasileiros. São Paulo: Ed. 34, 2006.

WHITAKER, D. C. A.; FIAMENGUE, E. C.; VELÔSO, T. M. G. (Org.). Ideologia e esquecimento: aspectos negados da memória social brasileira. Presidente Venceslau: Letras à Margem, 2010.

WHITAKER, D. C. A.; VELÔSO, T. M. G. (Org.). Oralidade e subjetividade: os meandros infinitos da memória. Campina Grande: EDUEP, 2005.

WILLEMART, P. A crítica genética na crítica literária. In: . Osprocessos de criação na escritura, na arte e na psicanálise. São Paulo: Perspectiva, 2009. p. 55-70.

WORCMAN, K. From domestic pot to ceramic doll: the story of Dona Izabel Mendes, doll maker of the Jequitinhonha Valley. Oral History Journal, v. 37, n. 2, p. 95-106, 2009.

WORCMAN, K.; PEREIRA, J. V. (Org.). História falada: memória, rede e mudança social. São Paulo: SESC São Paulo; Museu da Pessoa; Imprensa Oficial, 2006.

WORCMAN, K.; SANTOS, J. (Coord.). Todo mundo tem uma história pra contar. São Paulo: Olhares, 2012. 


\title{
Discografia
}

ANTONIO, Lincoln; FADEL, Georgette. Entrevista com Stela do Patrocínio. São Paulo: Independente, 2007. CD (47 min).

ROTHE, Iva. Aparecida. Belém do Pará: Na Music, 2010. CD (43 min).

\section{Videografia}

ELIANE. Direção: Ana Carolina de Moura Delfim Maciel e Caco Souza. 2007.

Resumo: A relação entre a história oral e o mundo das artes é assinalada por um paradoxo: embora as entrevistas sejam amplamente utilizadas para o estudo de diversas manifestações artísticas, o campo acadêmico que tem a entrevista em seu centro é pouco atento às questốes da arte. Neste artigo, examino esta situação e levanto hipóteses que podem ajudar a explicá-la. Após mapear as exceções nesse cenário e classificá-las conforme suas abordagens, sugiro duas articulações que podem ser promissoras para o estudo das artes por meio da história oral: a abordagem das ideias e dos conceitos artísticos explicitados em entrevistas e o estudo dos processos de criação.

Palavras-chave: história oral e memória, história da arte, crítica genética.

\section{Oral history and the arts: pathways, possibilities and challenges}

\begin{abstract}
The relationship between oral history and the arts is marked by a paradox: while interviews are widely used in the study of various art forms, the academic field of oral history, which situates interviews at its center, tends to neglect the arts. In this article, I examine this situation and propose several hypotheses that might explain it. After tracing a number of exceptions and classifying them according to their approaches, I suggest some promising paths to the arts using oral history, focusing on the artistic ideas and concepts articulated in interviews, as well as on the creative process itself.
\end{abstract}

Keywords: oral history and memory, art history, genetic criticism.

Recebido em 17/10/2012

Aprovado em 15/04/2013 